\title{
A new dawn for genetic association studies in multiple sclerosis
} OPEN

Orhun H. Kantarci, MD

Correspondence to Dr. Kantarci:

kantarci.orhun@mayo.edu

\section{Neurol Genet}

2016;2:e93; doi: 10.1212/ NXG.0000000000000093

\section{See article}

Before the genomics technology revolution allowed us to do genome-wide science, genetics research relied on our limited knowledge about a subject to generate hypothesis and candidate genes to study. Despite the level of naiveté, several associations with susceptibility to a complex disease such as multiple sclerosis (MS) were discovered. Of these, $H L A-D R B 1$ and $I L 7 R^{1}$ stand out as being confirmed and refined early by the genome-wide association studies (GWAS) that followed. ${ }^{2}$ Despite the expense and gargantuan efforts, these GWAS have successfully led to the discovery of more than 100 additional genes, albeit with smaller effect sizes, that contribute to MS susceptibility. ${ }^{3}$ This list keeps growing, but it comes with no surprise that most of these genes identified the immune system as one large candidate for MS susceptibility.

In the early days of "candidate-gene" research in MS, one of the interesting and arguably more clinically relevant questions was whether some biologically plausible candidates were indeed more relevant to phenotypic variability of MS than susceptibility. ${ }^{4}$ Could the same genes contribute to both susceptibility to and severity of MS? Is it possible that what we call susceptibility to MS is indeed one huge heterogeneous group of phenotypic variability masquerading as a single disease? If the answer is yes to both of these questions, we could also potentially explain the small effect size of various genes that have been identified. Several endophenotypic clusters of patients could be driving the associations that appear weak because of dilution by the massive population sizes of GWAS. The tricky part now is to separate these endophenotypic clusters and decide on the outcome measure to be used. After all, despite the heterogeneity in pathology and clinical disease course in MS, susceptibility is still a low-hanging fruit for genetic association studies. A patient can be defined as having MS much easier than defining the endophenotype they belong to. The latter issue can also be plagued by the variability of assessment of such phenotypes in multicenter study designs needed to recruit the right sample size.
In this issue of Neurology ${ }^{\circledR}$ Genetics, George et al., ${ }^{5}$ in a repurposing experiment (as opposed to a brandnew GWAS study), used susceptibility loci from previous MS GWAS experiments as candidate genes for potential severity determinants in MS. Their specific question was: Do the 52 risk alleles of MS also confer an increased severity of the disease analyzed by the Multiple Sclerosis Severity Score (MSSS)? The answer was a loud and clear NO.

First interpretation of this result would be that susceptibility and phenotypic variability genes potentially diverge as suggested previously. ${ }^{4}$ However, the problem may simply be the measure we are using as well. MSSS based on reranking of the Expanded Disability Status Scale (EDSS), essentially pushing the EDSS to normality in the studied population, may not be the most appropriate outcome when it comes to genotype-phenotype analyses. Another explanation for the negative finding could be that severity can potentially be affected by environmental factors such as life-long vitamin D availability, smoking, and obesity much more than susceptibility determined earlier in life. It is also possible that severity may still be a factor of multiple susceptibility variants acting in tandem in a given pathway to increase the effect of that pathway at an individual or subpopulation level. Finally, as is the case with all large studies to increase power, are we paradoxically missing an important signal just because of our assumption that each subpopulation of MS should behave similarly? Pooling patients for large studies might dilute the effect of such subpopulations. The studied population was selected based on having MS as a common denominator and not enriched for a specific phenotype under question. With all these possibilities, the current study raises many potential avenues to explore. This is just the dawn of such extensive studies targeting specific phenotypes. However, for success in such efforts, definition of biologically relevant phenotypes that can reliably be defined across centers is the key.

An example of such a proof-of-principle study recently demonstrated that $S C N 10 A$ polymorphisms

From the Department of Neurology, Mayo Clinic, Rochester, MN.

Funding information and disclosures are provided at the end of the editorial. Go to Neurology.org/ng for full disclosure forms. The Article Processing Charge for this editorial was waived at the discretion of the Editor.

This is an open access article distributed under the terms of the Creative Commons Attribution-NonCommercial-NoDerivatives License 4.0 (CC BY-NC-ND), which permits downloading and sharing the work provided it is properly cited. The work cannot be changed in any way or used commercially. 
that affect $\mathrm{Na}_{\mathrm{V}} 1.8$ expression in the cerebellum in MS but not in the normal brain can contribute to functional impairment in cerebellar-thalamic connectivity in MS. ${ }^{6,7}$ The clinical outcome studied was focused on the motor-cerebellar system under question, and findings were revealing for a future potential drug development strategy. These contemporary approaches to candidate gene studies pave the way forward. We certainly have the powerful genomic tools. Our next step is to pause, go back to bedside to develop the finetuned endophenotypes well beyond MSSS, and build the cohorts for the specific endophenotypes of MS.

\section{STUDY FUNDING}

No targeted funding reported.

\section{DISCLOSURE}

Funding for travel or speaker honoraria: (1) Istanbul MS Days, Novartis Pharmaceuticals, speaker honoraria payment to Mayo Clinic. No personal compensation. (2) Invited professor program, Biogen-Boston, speaker honoraria payment to Mayo Clinic. No personal compensation. Other activities: Grant review for The National Multiple Sclerosis Society. Research Support, Commercial Entities: Dr. Orhun H. Kantarci receives research support from the European Regional Development Fund (FNUSAICRC CZ.1.05/1.1.00/ 02.0123), the National Multiple Sclerosis Society, and has given a scientific presentation at a meeting supported by Teva Pharmaceuticals but has received no personal fees or personal compensation for this activity (all compensation for consulting activities paid directly to Mayo Clinic) nor has spoken about the specific medications involving this company. Dr. Kejal Kantarci (spouse) serves on the data safety monitoring board of Takeda Global Research and Development Center, Inc., and the data monitoring boards of Pfizer Inc. and Janssen Alzheimer Immunotherapy and is funded by the NIH (R01 AG040042 [PI], R21 NS066147 [PI], P50 AG44170/Project 2 [PI], P50 AG16574/Project 1 [PI], R01 AG11378 [Co-I], U19 AG10483 [Co-I] U01 AG042791 [Co-I]) and Minnesota Partnership for Biotechnology and Medical Genomics (PO03590201 [PI]). Research Support, Government Entities: Dr. Kejal Kantarci serves on the data safety monitoring board of Takeda Global Research and Development Center, Inc., and the data monitoring boards of Pfizer Inc. and Janssen Alzheimer Immunotherapy and is funded by the NIH (R01 AG040042 [PI], R21 NS066147 [PI], P50 AG44170/Project 2 [PI], P50 AG16574/Project 1 [PI], R01 AG11378
[Co-I], U19 AG10483 [Co-I] U01 AG042791 [Co-I]) and Minnesota Partnership for Biotechnology and Medical Genomics (PO03590201 [PI]). Research Support, Academic Entities: Dr. Kejal Kantarci serves on the data safety monitoring board of Takeda Global Research and Development Center, Inc., and the data monitoring boards of Pfizer Inc. and Janssen Alzheimer Immunotherapy and is funded by the NIH (R01 AG040042 [PI], R21 NS066147 [PI], P50 AG44170/Project 2 [PI], P50 AG16574/Project 1 [PI], R01 AG11378 [Co-I], U19 AG10483 [Co-I] U01 AG042791 [Co-I]) and Minnesota Partnership for Biotechnology and Medical Genomics (PO03590201 [PI]). Research Support, Foundations and Societies: 2006-2009 Multiple Sclerosis Society for support in multiple sclerosis research unrelated to this publication; 20082009 Mayo Foundation CR20 award for support in multiple sclerosis research unrelated to this publication; 2009-2011 Hilton Foundation support in multiple sclerosis research unrelated to this publication. Go to Neurology.org/ng for full disclosure forms.

\section{REFERENCES}

1. Zhang Z, Duvefelt K, Svensson F, et al. Two genes encoding immune-regulatory molecules (LAG3 and IL7R) confer susceptibility to multiple sclerosis. Genes Immun 2005;6: $145-152$.

2. International Multiple Sclerosis Genetics Consortium, Hafler DA, Compston A, et al. Risk alleles for multiple sclerosis identified by a genomewide study [see comment]. N Engl J Med 2007;357:851-862.

3. Beecham AH, Patsopoulos NA, Xifara DK, et al. Analysis of immune-related loci identifies 48 new susceptibility variants for multiple sclerosis. Nat Genet 2013;45: 1353-1360.

4. Kantarci $\mathrm{OH}$, de Andrade M, Weinshenker BG. Identifying disease modifying genes in multiple sclerosis. J Neuroimmunol 2002;123:144-159.

5. George MF, Briggs FBS, Shao X, et al. Multiple sclerosis risk loci and disease severity in 7,125 individuals from 10 studies. Neurol Genet 2016;2:e87. doi: 10.1212/ NXG.0000000000000087.

6. Roostaei T, Sadaghiani S, Park MT, et al. Channelopathyrelated SCN10A gene variants predict cerebellar dysfunction in multiple sclerosis. Neurology 2016;86:410-417.

7. Waxman SG, Kantarci O. The cerebellar channelopathy of multiple sclerosis. Neurology 2016;86:406-407. 


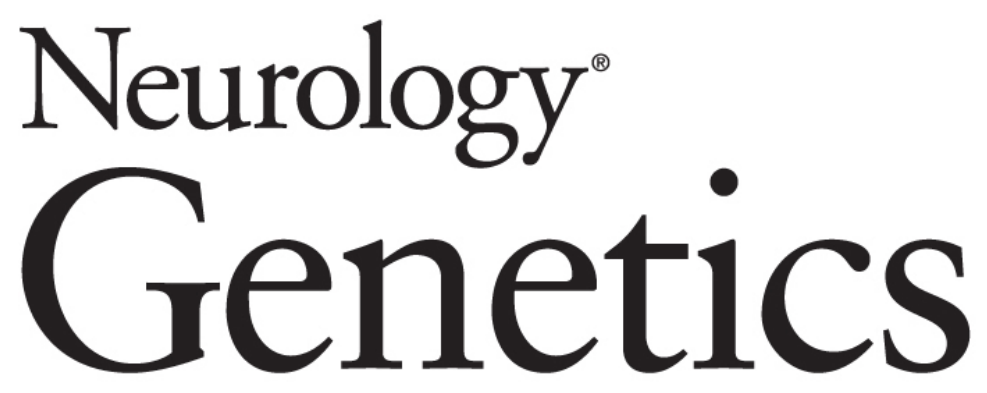

\section{A new dawn for genetic association studies in multiple sclerosis Orhun H. Kantarci \\ Neurol Genet 2016;2; \\ DOI 10.1212/NXG.0000000000000093}

This information is current as of August 4, 2016

\section{Updated Information \& Services}

\section{References}

Citations

Subspecialty Collections

Permissions \& Licensing

Reprints including high resolution figures, can be found at: http://ng.neurology.org/content/2/4/e93.full.html

This article cites 7 articles, 1 of which you can access for free at: http://ng.neurology.org/content/2/4/e93.full.html\#\#ref-list-1

This article has been cited by 1 HighWire-hosted articles: http://ng.neurology.org/content/2/4/e93.full.html\#\#otherarticles

This article, along with others on similar topics, appears in the following collection(s):

\section{All Genetics}

http://ng.neurology.org//cgi/collection/all_genetics

Autoimmune diseases

http://ng.neurology.org//cgi/collection/autoimmune_diseases

Multiple sclerosis

http://ng.neurology.org//cgi/collection/multiple_sclerosis

Information about reproducing this article in parts (figures,tables) or in its entirety can be found online at:

http://ng.neurology.org/misc/about.xhtml\#permissions

Information about ordering reprints can be found online: http://ng.neurology.org/misc/addir.xhtml\#reprintsus

Neurol Genet is an official journal of the American Academy of Neurology. Published since April 2015, it is an open-access, online-only, continuous publication journal. Copyright @ 2016 American Academy of Neurology. All rights reserved. Online ISSN: 2376-7839.

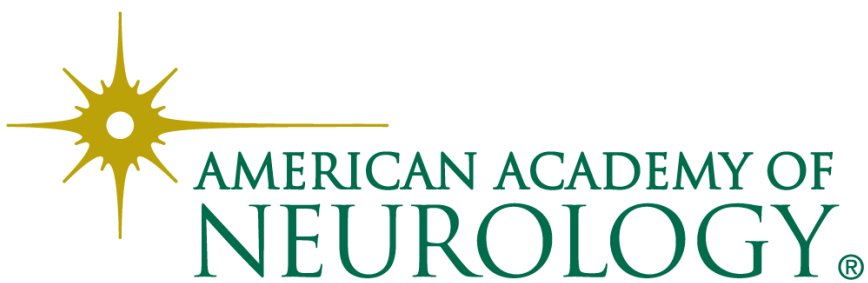

